\title{
The Third Party Funds and Non Performing Financing Rate on Murabahah
}

\author{
${ }^{1}$ DIAN HAKIP NURDIANSYAH, ${ }^{2}$ MUHAMMAD NASIM HARAHAP, \\ ${ }^{3}$ NURUL KHOTIMAH \\ 123 Universitas Singaperbangsa Karawang, Jl. HS Ronggowaluyo Teluk Jambe Timur, Indonesia \\ correspondence: ${ }^{1}$ dian.hakipnurdiansyah@staff.unsika.ac.id
}

\begin{abstract}
The function of Islamic Bank is a financial institution that conducts business activities based on the principles of Islamic Law and operational activities carried out through collecting funds from the public in the form of savings, current accounts, and deposits that will be disbursed by the bank to the public in the form of financing. The large funds raised by the bank will increase financial disbursed. The purpose of this research is to find out about Third Parties Fund, Non Performing Financing and Murabahah in PT Bank Syariah Mandiri and to analyze and explain them partially and simultaneously. Research method used is descriptive quantitative with data obtained from the quarterly financial statement of PT Bank Syariah Mandiri. The results show that Third Parties Fund, Non Performing Financing, and Murabahah continue to fluctuate. Meanwhile, the research hypothesis test shows that the variable of Third Parties Fund has a significant effect on Murabahah, while variable of Non Performing Financing has no significant effect on Murabahah.
\end{abstract}

Keywords: third parties fund, non performing financing rate, murabahah

\section{Introduction}

Islamic Bank is a bank that is operationally different from a conventional bank. Islamic banks have some characteristics, one of which is that it does not charge interest to customers, yet but the results as well as other compensation in accordance with the contracts agreement. The basic concept of sharia bank is based on Al-Qur'an and Hadith. All products and services offered should not conflict with the contents of the Qur'an and Hadith of Rasulullah SAW (Ismail, 2009). Hence, the establishment of interest-free banking institutions are expected to bring changes in order to improve the quality of the economy of Indonesian society.

Bank Syariah (Sharia Bank) in Indonesia has been protected by law since the issuance of Sharia Bank Legal Banking Law No. 7 of 1992 which was later revised into Law No. 10 of 1998 . However, since it is not yet specific and less accommodate the operational characteristics of Islamic banks, which on the other hand, the growth and volume of sharia bank business is growing quite rapidly, then Law No. 10 of 1998 is refined according to the banking situation as stated in Law No. 21 of 2008. It causes the existing financing in sharia banking is still dominated by financing based on the principle of selling and buying, such as murabaha (Iqbal, 2018).

PT Bank Syariah Mandiri is one of sharia-based commercial banks since its establishment in 1999. Similar to other banks, PT Bank Syariah Mandiri activities include fundraising and fund disbursement. The superior product of the channeling of funds in PT Bank Syariah Mandiri is through murabahah scheme. The following (table 1 ) is data on the increase in financing of PT Bank Syariah Mandiri in 2010 to 2016.

\section{Note: Akad means the agreement of}

The high demand for murabahah financing compared to other financing made this akad the focus of sharia bank activities. This is not in accordance with the main purpose

Received: 2020-03-28, Revised: 2020-05-05, Accepted: 2020-06-03. 
Table 1

The Increased Distribution of Financing at PT Bank Syariah Mandiri (Rp)

\begin{tabular}{lcccc}
\hline Financing & $\mathbf{2 0 1 0}$ & $\mathbf{2 0 1 1}$ & $\mathbf{2 0 1 2}$ & $\mathbf{2 0 1 3}$ \\
\hline Akad Murabahah & 12,676 & 19.773 & 27,549 & 33,207 \\
\hline Akad Musyarakah & 4,590 & 5.428 & 6.336 & 7,338 \\
\hline Akad Mudharabah & 4,240 & 4.671 & 4,273 & 3.908 \\
\hline Akad Murabahah & 2014 & 2015 & 2016 & \\
\hline Akad Musyarakah & 33.714 & 34,807 & 36,198 & \\
\hline Akad Mudharabah & 7,645 & 10,591 & 13,338 & \\
\hline
\end{tabular}

Source: Bank Sharia Mandiri Annual Report

of the establishment of Islamic financial institutions as an effort of the Muslims to underpin all aspects of economic life based on Al-Qur'an and Sunnah. Those efforts made by applying the system of profit and loss sharing or profit sharing (Antonio, 2008). Murabahah is a selling and buying goods at the initial sale price with an additional profit agreed. The seller should tell the cost of the purchased product and determine the rate of return in addition (Wiroso, 2011). This buying can be made based on orders and without orders.

Pursuant to article 4 of Law No. 21 of 2008, sharia banks are obliged to carry out the function of collecting and channeling funds. Current account (Giro), savings, and deposits are the form of funds gathering in the Sharia bank. As for the distribution of funds to customers, in the outline of sharia financing products, there are 4 categories differentiated based on the purpose of its use, namely: with the principle of buying and selling (Murabahah, Salam, and Istishna), with the principle of lease (Ijarah), with the principle of the outcome (Musyarakah and Mudharabah), and by the principle of auxiliary agreement (Hiwalah, Rahn, Ward, Wakalah and Kafalah).

To be able to distribute financing, banks need funding resources. One of the largest sources of banking funds comes from third party funds (DPK). This fund is obtained from the community collected through Giro, savings, and deposits. Then the funds collected by the bank will be channeled back in the form of financing.

Bank factor that must be considered in providing financing to the public is liquidity risk, namely Non Performing Financing (NPF). Non-performing financing or NPF is the ratio of non-performing financing to total financing disbursed by Islamic banks to the public. Based on the criteria set by Bank Indonesia, the categories included in the NPF are financing that is substandard, doubtful, and loss. Financing disbursed can trigger potential problems of financing. This research is conducted to discover how big the influence of the independent variable on the dependent variable. Based on the background of the problem that has been outlined, it can be identified that: first, the more portion of the financing of Murabahah on PT Bank Syariah Mandiri will raise the assumption that PT Bank Syariah Mandiri is the same as conventional Bank; the difference is only on the word credit that changed into financing. Second, the increase in the third party fund becomes a factor affecting the financing of Murabahah. Third, the decreased level of Non-Performing Financing at PT Bank Syariah Mandiri in the last two years has become the factor affecting the financing of Murabahah.

Based on the background and the formulation of the problem that has been described before, the researchers intend to conduct research with the following objectives: to analyze, acknowledge, and explain third party funds at PT Bank Syariah Mandiri, Non-Performing Financing of PT Bank Syariah Mandiri, Murabahah financing at PT Bank Syariah Mandiri, third party funds on the Murabahah financing at PT Bank Syariah Mandiri, the influence of Non-Performing Financing on PT Bank Syariah Mandiri, and the influence of third party funds and Non Performing financing rates on the financing of Murabahah at PT Bank Syariah Mandiri.

Murabahah financing is a channeling of funds for banks conducting business activities based on sharia principles in the form of provision and financing under the selling and buying agreement of goods at the cost of the principal plus the agreed profit margin 
between the bank and the customer whose payment is made by installment (Azmi, 2015).

According to PAPSI (Guidelines of Indonesian Islamic Banking Accounting Standards) 2013, Murabahah Financing is a fund from a bank to customers to purchase goods by confirming their purchase price to the buyer (the customer) and the buyer (the customer) pays it at a more favorable price.

Murabahah is a selling and buying agreement by stating the price of the item along with the profit on the selling of the item agreed upon by the seller (Zandi, Noraini, \& Shahabi, 2012). According to (Kariyoto, 2013), there are two types of Murabahah in the selling and buying activities based on the murabahah contract: murabahah without order and murabahah by order (murabahah to the purchase order). Murabahah without order is murabahah akad (akad means agreement) done regardless of whether there is orders or not, or will anyone buy it or not. Procurement of goods shall be made on the basis of minimum stocks to be maintained. In principle, in murabahah transaction, procurement of goods become the responsibility of Islamic banks as sellers. Murabahah by order (murabahah to the purchase order) can be categorized as the one with the nature of a binding or not binding the buyers to buy the goods ordered. Murabahah binding means the buyer must buy the goods ordered and can not cancel the order, while not binding means that despite ordering the goods the buyer is not bound to buy them (the buyer can accept it or cancel it) (Qolby, 2013)

Law No. 21 of 2008 concerning sharia banking states that "Deposits are funds entrusted by customers to sharia banks and/or UUS (Sharia Business Unit) based on wadiah or other contracts which are not contrary to sharia principles in the form of demand deposits, savings, or other forms likened to it ". Public funds deposited in banks are the largest source of funds that banks rely on the most consisting of 3 types: first is savings as deposits of third parties in the form of rupiah and foreign currency at the bank, withdrawals made only by a certain system of each issuing bank. Second is demand deposit as a public savings in the form of rupiah or foreign currency in a bank whose transactions (withdrawals and deposits) may be made at any time by means of pay using checks, bilyet giros (payment orders that cannot be cashed), ATM cards or by means of transfer of books. Third is deposited as a kind of savings services commonly offered by banks to the public. Deposits usually have a certain period in which money in them should not be withdrawn by customers (Vaidian \& Riduwan, 2016).

Third-Party Fund (DPK) deposits from the public entrusted to Islamic banks which may be withdrawn at any time without prior notice to the bank with certain drawdown media. Funds collected from the public are the largest sources of funds that banks rely on (reaching $80 \%-90 \%$ ). Deposit funds in Islamic banks are also able to be utilized by banks for sharia bank operational activities (Wardiantika \& Kusumaningtias, 2014). The third-party fund will then be used for bank operational activities, including in the case of loan disbursement. These resources are the most important source of funds for the bank's activities and a measure of success if the bank is able to finance its operations by this funding source (Kasmir, 2013). Third-party funds in this study can be mathematically formulated as follows:

\section{DPK = Giro + Deposits + Saving}

One of the risks faced by banks is the risk of unpaid financing that has been given or often called financing risk. Financing risks generally arise from various financing falling into the Non Performing Financing (NPF) category. According to Abusharbeh (2016), NPF is defined as the level of bad financing that had been reserved. It measures the assets of bank and describes the capacity of bank in spreading risks and recovering default loans.

Non-performing financing is a condition in which the customer is unable to pay part or all of its obligations to the bank as promised. Troubled financing or NPF will result in bank losses, i.e losses due to non-receipt of disbursed funds or unacceptable revenuesharing proceeds. Based on the criteria set by Bank Indonesia, the categories included in the NPF are substandard, doubtful, and loss. According to the damage, the credit risk is any risk associated with the failure of the client to pay its obligations or the risk that the debtors cannot repay their debts (Sholikhah, Pramuka, \& Adawiyah, 2017). Table 2 are the financing criteria for NPF calculations based on customers' paying ability.

NPF shows the ability of bank management in managing problematic financing provided by the bank. NPF is obtained by the following formula: the ratio 
Table 2

NPF Calculation Based on Customer's Purchase Ability (Debtors)

\begin{tabular}{|c|c|c|c|}
\hline \multirow{2}{*}{$\begin{array}{l}\text { Type of } \\
\text { Financing }\end{array}$} & \multicolumn{3}{|c|}{ Categories that are Taken into Account Within the NPF } \\
\hline & Not that smooth & Doubtful & Loss \\
\hline $\begin{array}{l}\text { Murabahah, } \\
\text { Istishna ', Ijarah, } \\
\text { Qard }\end{array}$ & $\begin{array}{l}\text { Overdue more than } 90 \\
\text { days up to } 180 \text { days }\end{array}$ & $\begin{array}{l}\text { Arrears more than } 180 \\
\text { days up to } 270 \text { days }\end{array}$ & $\begin{array}{l}\text { Overdue more than } 270 \\
\text { days }\end{array}$ \\
\hline Regards & Has matured up to 60 days & $\begin{array}{l}\text { It's falling } \\
\text { tempo up to } 90 \text { days }\end{array}$ & More than 90 days \\
\hline $\begin{array}{l}\text { Mudharabah, } \\
\text { Musharaka }\end{array}$ & $\begin{array}{l}\text { Arrears for up to } 90 \text { days } \\
\text { of profit sharing over } 30 \% \\
\text { to } 90 \% \text { of } \\
\text { income projects }\end{array}$ & $\begin{array}{l}\text { Overdue } \\
\text { from } 90 \text { to } 180 \\
\text { results; realization for } \\
\text { result less than } \\
30 \%\end{array}$ & $\begin{array}{l}\text { Arrears over } 180 \text { days; } \\
\text { less revenue realization } \\
\text { from } 30 \% \text { of the projected } \\
\text { income over } 3 \text { payment } \\
\text { periods. }\end{array}$ \\
\hline
\end{tabular}

Source: (Ihsan, 2011)

Table 3 Sharia Bank Non Performing Financing (NPF) Criteria

\begin{tabular}{|l|l|l|}
\hline No & NPF value & Predicate \\
\hline 1 & NPF $2 \%$ & Healthy \\
2 & $2 \% \leq$ NPF $5 \%$ & Healthy \\
\hline 3 & $5 \% \leq$ NPF $8 \%$ & Simply Healthy \\
\hline 4 & $8 \% \leq$ NPF $12 \%$ & Unwell \\
\hline 5 & NPF $\geq 12 \%$ & Not healthy \\
\hline
\end{tabular}

Source: SEBI No 9/24 / Dbps

is intended to measure the level of financing problems faced by sharia banks. When the ratio of NPF to a bank is high, it will result in the bank intermediation function is not working optimally because it reduces or decreases bank turnover, thereby minimizing the opportunity of bank to earn income. If the funds available in the bank is reduced, it will have an impact on the financing channeled to the community which automatically will also be reduced (table 3 ). This ratio value is then compared with the NPF criteria of sharia bank applied by Bank Indonesia as shown in the Table 3.

\section{Research Methodology}

This research uses descriptive method with quantitative approach. According to (Sugiyono, 2016) descriptive analysis is trying to describe the various characteristics of data derived from a sample. Based on the explanation, it can be concluded that the method of quantitative descriptive research is a research with the type of data derived from a sample in the population which then being analyzed using statistical methods in order to test the hypothesis that has been set. Quantitative descriptive research in this study aims to obtain results on how big the influence of Third Party Fund (DPK) and Non Performing Financing (NPF) level to murabahah financing at PT Bank Syariah Mandiri for the period of 2010 to 2017.

The research variable according to (Sugiyono, 2016) is everything in the form of whatever is determined by the researcher to be studied in order to obtain information about it, then draw conclusions out of it. According to the relationship between one variable and another, the variables used in this study are two variables: the first one is the independent variable that is the variable influences or is the cause of the change or the appearance of the dependent variable. The independent variables in this study are Third Party Funds (DPK) and Non Performing Financing (NPF) $\left(X_{1}\right.$ and $\left.X_{2}\right)$. The second one is a dependent variable that is a variable affected by or that is due because of the independent variable. The dependent variable in this study is Murabahah financing $(Y)$.

Classical Assumption Test. The classical assumption test is carried out to ensure that normality, autocorrelation, multicollinearity, and heteroscedasticity are not found in this study or the data generated are normally distributed. The classic assumption test consists of: 


\section{Normality Test}

The normality test has the objective to test whether or not in the regression model the dependent variable, independent variable or both are normally distributed. A good model is one that has a normal data distribution. To detect whether residuals are normally distributed or not, two methods are needed:

\section{Graph Method}

It is used to test data normality by looking at the normal probability plot that compares the actual cumulative distribution of data with the cumulative distribution of normal distribution. The normality test process can be detected by viewing at the spread of data (points) on the diagonal axis of the graph or by looking at the histogram of the residues, namely if the data spread around the diagonal line and follows the direction of the diagonal line or the histogram graph shows a normal distribution pattern, then the regression model meets the normality assumption. If the data spreads away from the diagonal and/or do not follow the direction of the diagonal line or the histogram graph does not show a normal distribution pattern, then the regression model does not meet the assumption of normality.

\section{Statistical Methods}

The statistical test used to test the assumption of normality is the normality test from Kolmogorov-Smirnov. To test whether a distribution of data normal or not is carried out by viewing the significance value of the variable: if it is significantly greater than $a=0.05$, then it shows the normal data distribution (Ghozali, 2016).

Descriptive statistics

According to (Sugiyono, 2016), descriptive statistics are statistics used to analyze data by describing or describing data that has been collected as it is without intending to make conclusions that apply to the public or generalizations. Research conducted on populations will obviously use descriptive statistics in their analysis. An overview of the data in this study consists of maximum, minimum, mean, and standard deviation that can be seen in the following Table 4.

Based on the results of descriptive statistic in table 4 above, it can be seen that the description of each variable is as follows: The result of descriptive statistic test of Murabahah Financing shows that the total value of Murabahah Financing of PT Bank Syariah Mandiri is Rp 815,478,601 with the average value of $\operatorname{Rp} 27,182,620.03$ and standard deviation of $9,055,763,663$. The descriptive statistical test result of Third Party Fund (DPK) shows that the overall value of Third Party Fund of PT Bank Syariah Mandiri is Rp1.497.160.688 with an average value of Rp 49.905.356,27 and the standard deviation of $14,646,281.04$.

It can also be seen that the lowest value of Third Party Fund of PT Bank Syariah Mandiri was Rp20,885,571 in the first quarter of 2010, while for the highest one was Rp 72,299,691 in the second quarter of 2017. Descriptive statistic test result of Non Performing Financing (NPF) shows that the overall value of Non Performing Financing of PT Bank Syariah Mandiri amounted to $74.02 \%$ with an average value of $2.47 \%$ and a standard deviation of $1.39 \%$. It can also be seen that the lowest value of Non Performing Financing of PT Bank Syariah Mandiri was $0.66 \%$ in the first quarter of 2010, while the highest value was $4.70 \%$ in the first quarter of 2015 .

Table 4

Descriptive Statistics Test Results

\begin{tabular}{lllllll}
\hline Descriptive Statistics & \multicolumn{7}{l}{} \\
& $\mathrm{N}$ & $\begin{array}{l}\text { Mini } \\
\text { mum }\end{array}$ & $\begin{array}{l}\text { Maxi } \\
\text { mum }\end{array}$ & Sum & Mean & $\begin{array}{l}\text { Std. Devi } \\
\text { ation }\end{array}$ \\
\hline Murabaha & 30 & 9058 & 3600 & 81547 & 27182 & 9055763.6630 \\
& & 568.0 & 6378.0 & 8601.0 & 620.030 & \\
\hline DPK & 30 & 2088 & 72299691.0 & 14971 & 49905 & 14646281.0400 \\
& & 5571.0 & & 60688.0 & 356.270 & \\
\hline NPF & 30 & .66 & 4.70 & 74.02 & 2.4673 & 1.39644 \\
\hline Valid N (listwise) & 30 & & & & & \\
\hline
\end{tabular}


Table 5

Operationalization of Variables

\begin{tabular}{|c|c|c|}
\hline Variables & Variable Concepts & Indicator \\
\hline $\begin{array}{l}\text { Third Party Funds (DPK) } \\
\left(\mathrm{X}_{1}\right)\end{array}$ & $\begin{array}{l}\text { Deposit funds from the community entrusted } \\
\text { to sharia banks, withdrawals may be made at } \\
\text { any time without prior notice to the bank with } \\
\text { certain withdrawal media (Adnan, Ridwan, } \\
\text { \& Fildzah, 2016; Syachfuddin \& Suherman, } \\
\text { 2017; Wanjare \& Motari., 2016; Wardiantika } \\
\text { \& Kusumaningtias, 2014) }\end{array}$ & \\
\hline $\begin{array}{l}\text { Non Performing Financing } \\
(\mathrm{NPF})\left(\mathrm{X}_{2}\right)\end{array}$ & $\begin{array}{l}\text { Ratio representing the number of nonperforming } \\
\text { financing to total financing. } \\
\text { (Alandejani \& Asutay, 2017; Azhar \& Nasim, } \\
\text { 2016; Prastanto, 2014; Rimadhani \& Erza, } \\
\text { 2017) }\end{array}$ & \\
\hline Murabahah Financing (Y) & $\begin{array}{l}\text { Murabahah is a selling transaction of goods } \\
\text { by stating the price of acquisition (the cost } \\
\text { of good purchase) and profit (margin) agreed } \\
\text { by the seller and buyer. (Anjani \& Hasmarani, } \\
2016 \text {; Bowo, 2013; Irfan, 2012; Nawawi, } \\
\text { Nurdiansyah, \& Al Qodliyah, 2018) }\end{array}$ & $\begin{array}{l}\text { Murabahah Financing } \\
=\text { Total Financing } \\
\text { Murabahah Distributed }\end{array}$ \\
\hline Murabahah Financing (Y) & $\begin{array}{l}\text { Murabahah is a selling transaction of goods } \\
\text { by stating the price of acquisition (the cost } \\
\text { of good purchase) and profit (margin) agreed } \\
\text { by the seller and buyer. (Anjani \& Hasmarani, } \\
2016 \text {; Bowo, 2013; Irfan, 2012; Nawawi, } \\
\text { Nurdiansyah, \& Al Qodliyah, 2018) }\end{array}$ & \\
\hline
\end{tabular}

\section{Operationalization of Variables}

The relation between variables, subvariables, and indicators in the instrument is shown in Table 5.

Method of collecting data. The population in this study is the financial statements of PT Bank Syariah Mandiri in 2010-2017. The sampling technique in this research is purposive sampling or also called judgmental sampling which is used by determining the specific criteria to the sample. In this research, the sample used is a quarterly financial report of PT Bank Syariah Mandiri in 2010 - 2017. The quarterly financial report was chosen to find out the information of the independent variable carefully and to increase the amount of the research sample.

\section{Population}

The population is an area of generalization consisting of objects/subjects that have certain qualities and characteristics set by researchers to learn and then withdraw a conclusion. Thus, the population is not just people, but also objects and other natural objects (Sugiyono, 2015:80). The population in this research is the financial statement of PT Bank Syariah Mandiri in 2010-2017.

\section{Sample}

According to Sugiyono (2015:81), samples are part of the number and characteristics of the population. The sampling techniques in this study are purposive sampling or also called sampling judgmental used to determine the specific criteria of the sample. In this research, the samples used are the quarterly financial statements of PT Bank Syariah Mandiri in the years 2010 - 2017. Quarterly financial statements are selected due to the thorough information of independent variables and to enlarge the number of samples of research.

Types and Data sources. The data used in this research is the secondary data in the quarterly financial statement of PT Bank Syariah Mandiri in the period 20102017. Secondary Data comes from the official website of PT Bank Syariah Mandiri (http:// www.syariahmandiri.co.id).

Data Collection Techniques. The data collection techniques used in this research are obtained through the following ways:

Library Research. The research is conducted by studying and understanding the data obtained from various literature, such 
as magazines, newspapers, printed books, articles, and websites/Internet related to the discussion of this research.

Documentation method. It is the record of an event that has passed in writing, drawing, or monumental works of a person. Documents are written are in the form of a diary, history of life (life history), stories, biography, and policy regulation (Sugiyono, $2015: 240$ ). By this method, the author collects the financial report data of PT Bank Syariah Mandiri which has been published in the period of 2010 to 2017 regarding the variables that will be examined in this research, namely DPK, NPF, and Murabahah financing. The data consists of a financial position report (balance sheet) and financial ratios report.

\section{Results and Discussion}

\section{Research result}

This study aims to determine the effect of Third Party Funds (DPK) and the level of Non Performing Financing (NPF) on Murabahah financing. Dependent variable in this research is Murabahah financing, while independent variables are Third Party Fund (DPK) and level of Non Performing Financing (NPF). This study uses secondary data in the form of quarterly financial statements of PT Bank Syariah Mandiri obtained from the official website of PT Bank Syariah Mandiri (http://www.syariahmandiri.co.id).

Based on the results of research that has been done on Third Party Fund, Non Performing Financing, and Murabahah Financing in PT Bank Syariah Mandiri for 2010-2017 period, description of each research variable are as follows:

\section{Third Party Funds in PT Bank Syariah Mandiri}

Third Party Funds (DPK) fluctuated during the period of 2010-2017 but tended to increase. This explained why the deposits in 2010-2014 increased, then decreased in the first quarter of 2015, and increased again in third quarter of 2015 which indicated the increasing public trust to PT Bank Syariah Mandiri (Harianto, Mizan, Al Amin, \& Meilvinasvita, 2019). The average of Third Party Funds in PT Bank Syariah Mandiri amounted to Rp49,905,356 with a minimum amount of Rp $20,885,571$ in the first quarter of 2010 and a maximum amount of $\mathrm{Rp}$ $72,299,691$ in the second quarter of year 2017.

\section{Non Performing Financing at PT Bank Syariah Mandiri}

Non Performing Financing (NPF) fluctuated during the period of 2010-2017 but tended to increase that caused by many factors, both from the internal and external factors of PT Bank Syariah Mandiri such as the existence of intentional nature of the customer (Havidz \& Setiawan, 2015; Maidalena, 2014; Muratova et al., 2003; Setiawan \& Indriani, 2016). However, although it tends to increase, Non Performing Financing at PT Bank Syariah Mandiri is still within the limits of the provisions applied by Bank Indonesia of $<5 \%$. One way offered by PT Bank Syariah Mandiri to reduce the level of Non-Performing financing is by improving the analytical skills of human resources for the marketing trust of the entire branch through the ever and improvement of HSSE (Logistics. Health, Safety, Security \& Environmental) policy as well as EMI (Equated Monthly Installments) standards in conducting financing analysis.

The average amount of Non Performing Finance (NPF) financing at PT Bank Syariah Mandiri is $2.0 \%$, with a minimum amount of $0.2 \%$ in I quarter of year 2010 and the maximum amount of \% that occurred in II quarter of year 2015.

\section{Murabahah Financing at PT Bank Syariah Mandiri}

Murabahah financing fluctuated during the period of 2010-2017. Murabahah Financing in 2010-2015 in the second quarter was increased, and from the third quarter of 2015 to second quarter of 2017, Murabahah financing at PT Bank Syariah Mandiri continued to decline and increase but tended to increase each year (Afif, 2014; Ahmed, Sabirzyanov, \& Rosman, 2016; Rahmawaty, 2007). It happened because Murabahah financing is the most dominating in PT Bank Syariah Mandiri. With the high demand of Murabahah financing at PT Bank Syariah Mandiri, it became the focus in bank activities as Murabahah Financing is considered to be less risky than the financing of profit sharing that should be the focus of sharia banks (Ihsan, 2011; Umiyati \& Ana, 2017).

The average for Murabahah Financing 
in PT Bank Syariah Mandiri amounted to Rp $27,182,620$ with a minimum amount of $\mathrm{Rp}$ $9,058,568$ in the first quarter of 2010 and a maximum amount of $\mathrm{Rp} 36,006,378$ occurred in the first quarter of IV, 2016.

\section{The Influence of Third Party Funds on Murabahah Financing at PT Bank Syariah Mandiri}

Based on the result of statistical analysis, Third Party Fund variable shows that the regression coefficient is positive with the value equal to 1.244 , which means if there is an increase in Third Party Fund, then it will increase Murabahah Financing value being distributed.

$T$ test results obtained is equal to 18.306 with a significance value of 0.000 . When it compared with the value of $t$ table of 2,05183 , it will be obtained $t$ count $>t$ table of (18.306> 2.05183) and significance level of $0,000<0.005$. This indicates that $H_{1}$ is accepted and $\mathrm{H}_{0}$ is rejected.

From the results of the analysis, it can be concluded that the Third Party Fund has a significant effect on Murabahah Financing. If the Third Party Funds in PT Bank Syariah Mandiri is increasing, it will also improve Financing Murabaha channeled by PT Bank Syariah Mandiri. Since the purpose of the bank is to make profit, then the bank is not going to idle the funds granted. Banks tend to channel the funds saved as much as possible to gain maximum benefit.

These results also support the research conducted by (Vaidian \& Riduwan, 2016) which stated that the DPK has a significant positive effect on the financing of Murabaha.

\section{The Effect of Non Performing Financ- ing on Murabaha Financing at PT Bank Syariah Mandiri}

Based on the results of statistical analysis, the third party fund variable indicating that the regression coefficient has a negative value of-0.008, which means if Non Performing Financing is increased by one unit, it will lower the value of the Murabahah financing distributed.

T test results obtained at -0.462 with a significance value of 0.648 . When compared with $t_{\text {table }}$ value of 2.05183 , it will be obtained the result of $t_{\text {count }}>t_{\text {table }}$ of $(-0.462<2.05183)$ and the significance level of $0.648>0.005$. This shows that the $\mathrm{H} 2$ is rejected and $\mathrm{HO}$ is accepted.

From the results of the analysis, it can be concluded that Non Performing Financing has no significant effect on the Murabahah financing, but it does not mean the absence of Non Performing Financing is against the Murabahah financing. The effect is there but not too meaningful. This is because the development of Non Performing Financing at PT Bank Syariah Mandiri continues to fluctuate and is at a normal range, so that it does not affect the Murabahah financing conducted by PT Bank Syariah Mandiri.

The results of the study also supported the research conducted by (Azmi, 2015) stating that the NPF has no effect on Murabahah financing. The results also support the research conducted by Fika Azmi (2015) and (Abusharbeh, 2016) which states that the NPF has no effect on the financing of Murabaha.

The Effect of Third Party Fund (DPK) and the level of non-performing financing (NPF) on Murabaha Financing at PT Bank Syariah Mandiri

The value of $F$ arithmetic amounted to 365.286 with a significance level of 0.000 . As for the $F$ table at a significance level of $5 \%$ is 3,35 (DF1 $=\mathrm{k}-1$ and DF2 = nk). Thus, $F$ count $>F$ table $(365.286>3.35)$ and the significance value $0.000<0.05$. This shows that $\mathrm{H}_{3}$ received and $\mathrm{H}_{0}$ is rejected, which means that the Third Party Funds and Non Performing Financing simultaneously affect the Financing Murabaha at PT Bank Syariah Mandiri for the period of 2010-2017, This is in accordance with the research conducted by (Boyson, Gantchev, \& Shivdasani, 2017; Fallon, 2015; Spicer \& Johnson, 2004).

\section{Conclusions}

Third Party Funds (TPF) in PT Bank Syariah Mandiri has fluctuated over the period of 2010 to 2017 but tended to increase each year. This indicates the increasing public confidence in PT Bank Syariah Mandiri. In the other hand, the level of Non Performing Financing (NPF) has fluctuated over the period of 2010 to 2017 but tended to increase. However, although likely to increase, Non Performing Financing at PT Bank Syariah Mandiri is still within the limits of the provisions adopted by Bank Indonesia, which is less than five percent. 
Financing of Murabaha has fluctuated over the period of 2010-2017 but tended to increase each year. This makes Murabaha financing as the most dominating program at PT Bank Syariah Mandiri. Financing of Murabaha at PT Bank Syariah Mandiri became the focus of the activities of banks because Financing Murabaha rated more with minimal risk compared with the financing for the results that should be the focus of Islamic banks. The level of Non Performing Financing has no significant effect on Financing Murabaha at PT Bank Syariah Mandiri.

\section{Acknowledgment}

Thank you to the unsika's rector who supports this research, so that this research can be completed.

\section{References}

Abusharbeh, M. T. (2016). Analysis the Effect of Islamic Banks Performance on Depositor's Fund: Evidence from Indonesia. International Journal of Economics and Finance, 8(10), 40. https://doi.org/10.5539/ijef.v8n10p40

Adnan, A., Ridwan, R., \& Fildzah, F. (2016). Pengaruh Ukuran Bank, Dana Pihak Ketiga, Capital Adequacy Ratio, dan Loan To Deposit Ratio Terhadap Penyaluran Kredit Pada Perusahaan Perbankan yang Terdaftar Di Bursa Efek Indonesia Tahun 2011-2015. Jurnal Dinamika Akuntansi Dan Bisnis. https://doi.org/10.24815/ jdab.v3i2.5386

Afif, Z. N. (2014). Pengaruh Pembiayaan Murabahah Terhadap Laba Melalui Variabel Intervening Pembiayaan Bermasalah Bank Umum Syariah Di Indonesia Periode 20092013. Jestt.

Ahmed, M. U., Sabirzyanov, R., \& Rosman, R. (2016). A critique on accounting for murabaha contract: A comparative analysis of IFRS and AAOIFI accounting standards. Journal of Islamic Accounting and Business Research. https://doi. org/10.1108/JIABR-04-2016-0041

Alandejani, M., \& Asutay, M. (2017). Nonperforming loans in the GCC banking sectors: Does the Islamic finance matter? Research in International Business and Finance. https://doi.org/10.1016/j. ribaf.2017.07.020

Anjani, R., \& Hasmarani, M. I. (2016). Pengaruh pembiayaan mudharabah, musyarakah dan murabahah terhadap profitabilitas BPRS di Indonesia periode 2012-2015. Jurnal Ekonomi \& Keuangan
Islam. https://doi.org/10.20885/jeki. vol2.iss2.art5

Antonio, M. S. (2008). Bank Syariah Dari Teori Ke Praktik. Jakarta: Gema Insani.

Azhar, I., \& Nasim, A. (2016). Pengaruh Pembiayaan Jual Beli, Pembiayaan Bagi Hasil, Dan Non Performing Finance Terhadap Profitabilitas (Studi Kasus Pada Bank Umum Syariah Di Indonesia Periode 2012 - 2014). Jurnal ASET (Akuntansi Riset). https://doi.org/10.17509/jaset. v8i1.4021

Azmi, F. (2015). Faktor Internal Dan Eksternal Yang Mempengaruhi Pembiayaan Murabahah Pada Perbankan Syariah Di Indonesia. Graduasi. https://doi. org/10.1354/vp.44-6-893

Bowo, F. A. (2013). Pengaruh Pembiayaan Murabahah terhadap Profitabilitas. Jurnal Studia Akuntansi Dan Bisnis.

Boyson, N. M., Gantchev, N., \& Shivdasani, A. (2017). Activism mergers. Journal of Financial Economics. https://doi. org/10.1016/j.jfineco.2017.06.008

Fallon, T. (2015). The new silk road: Xi jinping's grand strategy for eurasia. American Foreign Policy Interests. https:// doi.org/10.1080/10803920.2015.1056 682

Ghozali, I. (2016). Aplikasi Analisis Multivariate dengan Program IBM SPSS 21 :Update PLS Regresi. Semarang. https://doi. org/10.2307/1579941

Harianto, S., Mizan, Al amin, H., \& Meilvinasvita, D. (2019). Dosen Politeknik Negeri Lhokseumawe Program Studi Akuntansi Lembaga Keuangan Syariah. Jurnal Ekonomi Dan Bisnis, 21(1), 21-28.

Havidz, S. A. H., \& Setiawan, C. (2015). Bank Efficiency and Non-Performing Financing (NPF) in the Indonesian Islamic Banks. Asian Journal of Economic Modelling. https://doi.org/10.18488/ journal.8/2015.3.3/8.3.61.79

Ihsan, M. (2011). Pengaruh Gross Domestic Product, Inflasi, Dan Kebijakan Jenis Pembiayaan Terhadap Rasio Non Performing Financing Bank Umum Syariah Di Indonesia Periode 2005 Sampai 2010. Skripsi Universitas Diponegoro Semarang. https://doi. org/10.1142/9789812775719_0017

Iqbal, M. (2018). Analysis of Factors Affecting Murabahah Financing in Shariah, (November 2013).

Irfan, Q. (2012). Murabaha Financing vs. Lending on Interest. SSRN Electronic Journal. https://doi.org/10.2139/ ssrn. 1803651 
Ismail. (2009). Perbankan Syariah. Jakarta: Kencana.

Kariyoto. (2013). Akuntansi dalam Perspektif Syariah Islam . Akuntansi Dalam Perspektif Syariah Islam.

Kasmir. (2013). Ruang Lingkup Lembaga Keuangan Bank. In Bank dan Lembaga Keuangan Lainnya.

Maidalena. (2014). Analisis Faktor Non Performing Financing ( NPF ) pada Industri Perbankan Syariah. Human Falah.

Muratova, A., Hübner, T., Narula, N., Wand, H., Turkovskaya, O., Kuschk, P., ... Merbach, W. (2003). Rhizosphere microflora of plants used for the phytoremediation of bitumen-contaminated soil. Microbiological Research, 158(2), 151-161. https://doi. org/10.1078/0944-5013-00187

Nawawi, A., Nurdiansyah, D. H., \& Al Qodliyah, D. S. A. (2018). Pengaruh Pembiayaan Mudharabah dan Musyarakah Terhadap Profitabilitas (ROA) Pada BPRS HIK Bekasi Kantor Cabang Karawang. FALAH: Jurnal Ekonomi Syariah, 3(2), 96. https://doi. org/10.22219/jes.v3i2.7679

Prastanto. (2014). Accounting Analysis Journal. Accounting Analysis Journal, 3(4), 457-465.

Qolby, M. L. (2013). Faktor - Faktor Yang Mempengaruhi Pembiayaan Pada Perbankan Syariah Di Indonesia Periode Tahun 2007 - 2013. Economics Development Analysis Journal, 2(4), 367-383. https://doi.org/10.15294/edaj. v2i4.3206

Rahmawaty, A. (2007). Ekonomi Syari'ah: Tinjauan Kritis Produk Murabahah dalam Perbankan Syari'ah di Indonesia. La_Riba. https://doi.org/10.20885/lariba.vol1.iss2. art3

Rimadhani, M., \& Erza, O. (2017). Analisis Variabel-Variabel Yang Mempengaruhi Pembiayaan Murabahah Pada Bank Syariah Mandiri Periode 2008.01-2011.12. Media Ekonomi. https://doi.org/10.25105/ me.v19i1.833

Setiawan, U. N. A., \& Indriani, A. (2016). Pengaruh Dana Pihak Ketiga (DPK), Capital Adequacy Ratio (CAR), dan Non Performing Financing (NPF) terhadap Profitabilitas Bank Syariah dengan Pembiayaan sebagai Variabel Intervening. Diponegoro Journal of Management.

Sholikhah, Z., Pramuka, B. A., \& Adawiyah, W. R. (2017). Determinant of the equity based financing volume : A case of Islamic banks in Indonesia. Research Journal of Finance and Accounting.

Spicer, A. J., \& Johnson, M. R. (2004). Thirdparty demanufacturing as a solution for extended producer responsibility. Journal of Cleaner Production. https://doi. org/10.1016/S0959-6526(02)00182-8

Sugiyono. (2016). Memahami Penelitian Kualitatif. Bandung: Alfabeta. Bandung.

Syachfuddin, L. A., \& Suherman, R. (2017). Pengaruh Faktor Makro Ekonomi, Dana Pihak Ketiga dan Pangsa Pembiayaan Terhadap Profitabilitas Industri Perbankan Syariah di Indonesia Tahun 2011-2015. Jurnal Ekonomi Syariah Teori Dan Terapan. https://doi.org/10.20473/ VOL4ISS201712PP977

Umiyati, \& Ana, L. T. (2017). Faktor-Faktor Yang Mempengaruhi Pembiayaan Pada Bank Umum Syariah Devisa Di Indonesia Umiyati. Jurnal Ekonomi Dan Perbankan Syariah.

Vaidian, E. V., \& Riduwan, A. (2016). Determinan Pembiayaan Murabahah (Studi Kasus Pada PT. Bank Muamalat Indonesia, Tbk). Jurnal IImu Dan Riset Akuntansi, 5(11), 1-16.

Wanjare, J., \& Motari., M. (2016). Interest Rate Variations And The Profitability of Islamic Banks In Kenya. International Journal of Advanced Research, 4, 17-26. https://doi.org/10.21474/ijar01/591

Wardiantika, L., \& Kusumaningtias, R. (2014). Pengaruh Dpk, Car, Npf, Dan Swbi Terhadap Pembiayaan Murabahah Pada Bank Umum Syariah Tahun 2008-2012. Ifstin Jurnal IImu Manajemen (JIM), 2(4), 12-22.

Wiroso. (2011). Produk Perbankan Syariah, E - Book. Jakarta: LPFE Usakti.

Zandi, G., Noraini, M. A., \& Shahabi, A. (2012). Analisis Implementasi Manajemen Kualitas Dari Kinerja Operasional Pada Industri Ekstraktif Di Sulawesi Utara (Studi Komparasi Pada Pertanian, Perikanan, dan Peternakan). African Journal of Business Management, 6(24), 7066-7073. https:// doi.org/10.31843/jmbi.v5i1.138. 